Volume 11

Issue 1 Information and Communications

Technologies in Mass Atrocities Research and

Article 16 Response

$5-2017$

\title{
Book Review: The Rohingyas: Inside Myanmar's Hidden Genocide
}

Suwita Hani Randhawa

University of Oxford and University College London

Follow this and additional works at: https://digitalcommons.usf.edu/gsp

\section{Recommended Citation}

Randhawa, Suwita Hani (2017) "Book Review: The Rohingyas: Inside Myanmar's Hidden Genocide,"

Genocide Studies and Prevention: An International Journal: Vol. 11: Iss. 1: 119-121.

DOI:

http://doi.org/10.5038/1911-9933.11.1.1473

Available at: https://digitalcommons.usf.edu/gsp/vol11/iss1/16

This Book Review is brought to you for free and open access by the Open Access Journals at Digital Commons @ University of South Florida. It has been accepted for inclusion in Genocide Studies and Prevention: An International Journal by an authorized editor of Digital Commons @ University of South Florida. For more information, please contact digitalcommons@usf.edu. 
Book Review: The Rohingyas: Inside Myanmar's Hidden Genocide

\author{
Suwita Hani Randhawa \\ University of Oxford \\ Oxford, United Kingdom
}

The Rohingyas: Inside Myanmar's Hidden Genocide

Azeem Ibrahim

London, Hurst \& Company, 2016

160 Pages; Price: \$19.95 Hardcover

Reviewed by Suwita Hani Randhawa

University of Oxford

At a time when the plight of the Rohingyas - a Muslim confessional group living in the Rakhine province of western Myanmar-are receiving increasing international attention, Azeem Ibrahim's new book is a timely intervention. The book's core message is plain and clear: Myanmar currently stands on the edge of genocide and without decisive action by the international community, the long-standing persecution, discrimination and violence the Rohingyas have suffered since Myanmar's independence in 1948 will escalate into full-scale genocide. The situation the Rohingyas have faced, and which they continue to confront, needs to be appreciated as a text-book case of pre-genocide, Ibrahim forcefully asserts. For almost seventy years, the Rohingyas have faced systematic oppression and persecution, which has been both orchestrated and facilitated by Myanmar's military regime: they have been denied legal citizenship and are therefore stateless in their own country; their economic livelihood has been dismantled through economic boycotts; their participation in electoral processes has been restricted; mosques in their local communities have been destroyed; restrictions have been placed on their ability to marry and to have children; their access to health and education has been curtailed; and there are regular attacks, massacres and acts of violence being committed against them.

Demonstrating how and why the situation faced by the Rohingyas merits the charge of genocide is, moreover, accompanied by a further objective, namely, to challenge conventional narratives that currently pervade contemporary political assessments of Myanmar. In doing so, Ibrahim presents a critical reassessment of commonly-accepted claims about Myanmar. Firstly, far from being a closed country that is internationally isolated, the military regime has consciously and consistently maintained external links with the rest of the international community. Secondly, the global praise Aung San Suu Kyi-the leader of the country's main opposition party, the National League for Democracy (NLD) - often receives for her long-standing commitment to a democratic future for Myanmar often obscures the fact that her domestic political support, as well as that of her party, comes almost entirely from the ethnically Burman community, who are mainly Buddhists. Like the military regime, therefore, the NLD has, and continues to have, a difficult relationship with nonBuddhist ethnic minorities in Myanmar. Finally, instances of inter-communal violence in Myanmar are not simply a predictable side-effect of the country's difficult transition from authoritarian military rule to democracy. Rather, Buddhism has played an instrumental role in facilitating intercommunal violence in Myanmar, particularly because it has been consciously employed by the military regime, as well as religious actors like Buddhist monks, to construct a nationalist discourse that is essentially exclusivist in character.

A greater appreciation of these political dynamics, Ibrahim argues, is central towards understanding how and why the Rohingyas have been the target of continued persecution and violence, as well as why there has been a conspicuous absence of domestic and international action aimed at reversing this state of affairs. While it is conventional to view Myanmar as an isolated state governed by military rulers who are deeply suspicious of external powers, Ibrahim pertinently demonstrates how this fear has co-existed with an economic imperative to maintain international trade links, as well as calculated decisions concerning Myanmar's approach to international relations. On the one hand, the military regime is cognisant that foreign investment 
from regional powers such as China, India, South Korea and Australia - particularly in the spheres of telecommunications, oil, gas and real estate-presents it with significant economic and political dividends. Given the military's control over the Myanmar's economy, it is unsurprising that the regime personally profits from greater trade and investment links. However, these economic gains also brings significant political benefits for the military regime. Keen to safeguard their commercial interests in a country that presents them economic opportunities to exploit, regional powers presently investing in Myanmar are reluctant to either criticize the military regime for its treatment of the Rohingyas or to intervene in the matter directly.

On the other hand, the military regime has consciously made strategic foreign policy decisions, which additionally serves to shield its domestic policies, especially those in connection with the Rohingyas, from international pressure and scrutiny. Here, Ibrahim argues a calculated decision to make North Korea one of its key allies - a relationship that has been marked by the trading of food in exchange for advanced weaponry - provides the military regime with an important bargaining card vis-à-vis the United States (US) and the European Union (EU). Concern with Myanmar's relationship with North Korea effectively means Western states cannot afford to unnecessarily antagonize the military regime, as they fear it could force Myanmar to deepen its existing links with North Korea. The US and the EU, therefore, have had to content themselves with the limited democratic reforms the military regime has introduced within the country. And indeed, discernible political changes within the country - the current openness of its economy, an international-friendly opposition leader and freer national elections - have largely fed into the prevailing narrative that Myanmar is progressively moving, slowly but surely, towards democracy. According to Ibrahim, however, this has meant that the situation facing the Rohingyas has been dismissed as an inevitable bump along Myanmar's road to democracy, rather than being seen as an urgent matter that merits greater international attention.

Domestic political dynamics also fundamentally conspire against the Rohingyas, Ibrahim contends. Although Aung San Suu Kyi and her NLD opposition party are electorally popular, they are not, contrary to popular belief, a mass party with either widespread or entrenched political support amongst Myanmar's diverse ethnic groups. Rather, its electoral base comes primarily from the Burman ethnic community, who are mostly Buddhists. In order to maintain a political connection with the Burmese electorate, therefore, the NLD is fundamentally reliant upon Buddhist monks and consequently, it has formed alliances with organized Buddhist monks. Worryingly, this has included political dealings with the 969 Movement - a grouping of extremist, anti-Islamist Buddhist monks who have been instrumental in perpetrating and encouraging violence against Myanmar's Muslim communities. Despite its democratic credentials and its status as the country's opposition, therefore, the NLD has found it politically convenient to remain silent on the question of the Rohingyas and anti-Muslim violence. And indeed, Aung San Suu Kyi herself, Ibrahim notes, has frequently avoided direct comment when the question of the systematic persecution of the Rohingyas is raised. Popular connotations of Buddhism as a benign and peaceful religion - which, in turn, predominantly centre on images of yoga, meditation and mindfulness - fail to appreciate, Ibrahim therefore argues, how Buddhism in Myanmar has had a much more menacing role. In particular, the politically explosive way in which religion and politics has become intertwined in Myanmar has played a significant role in enabling the legal, political, economic and social persecution of the Rohingyas. The fusing of Buddhism and Burmese nationalism has, in Ibrahim's assessment, fundamentally contributed to an exclusivist nationalist discourse that presents Muslims and Islam as a fundamental threat, both to Buddhism's and that state's continued existence.

This, then, is not a book that simply makes a passionate plea on behalf of an ethnic group whose predicament has been domestically and internationally neglected. Rather, it is simultaneously a commentary on contemporary politics in Myanmar but crucially, one grounded in a deep appreciation of how Myanmar's colonial and post-independence history has contributed to some of the pressing political problems it faces today. The book, therefore, successfully speaks to multiple audiences. Historians will find Ibrahim's account of Myanmar's history especially interesting, particularly because he takes issue with contemporary historians who, like extremist Buddhist monks and the military regime, maintain that the Rohingyas were never original inhabitants of Burma. It bears mentioning, too, that for those unacquainted with the history and politics of 
Myanmar, this book is an invaluable resource. In addition, political scientists and lawyers will find Ibrahim's analysis of the legal discrimination effected upon the Rohingyas through exclusionary citizenship laws bears relevance to broader politico-legal questions, such as how the legal machinery of the state can be utilized to achieve broader political objectives. And from his assessment of Myanmar's foreign policy and its external relations, international relations scholars will be able to draw important insights on what still remains an under-explored issue, namely, how a peripheral Southeast Asian state still manages to influence the contours of regional and international politics from the margins. Finally, Ibrahim's engagement with the scholarly literature on genocide will be of interest to both international lawyers and genocide scholars. Although his comparative analysis of the impending genocide of the Rohingyas with past genocides in Armenia, Germany and Rwanda is somewhat brief and cursory, it nevertheless invites more research, particularly from the perspective of genocide studies, to be conducted in connection with the Rohingyas.

The book concludes with a set of policy prescriptions, which are aimed at reversing the current state of domestic and international inaction over the Rohingyas. Cognisant that any solution would require action on multiple fronts, Ibrahim finds it crucial to focus efforts on the following: firstly, increase the levels of external pressure upon the military regime; refer past instances of mass violence to the International Criminal Court (ICC); and finally, intensify pressure on the domestic front. While this combination of domestic and international action appears politically constructive, Ibrahim's vision of the way forward raises a great number of questions, all of which are left unexplored in the book. For instance, Ibrahim identifies four key external actors - the United Nations (UN), the US, China and the Association of Southeast Asian Nations (ASEAN) - as having a role to play in increasing political pressure on the military regime for its treatment of the Rohingyas. However, exactly what this pressure should entail remains vague and unclear: international condemnation, sanctions, suspension of trade links, or outright international intervention? What is equally missing in Ibrahim's analysis is an assessment of the political feasibility, as well as the possible constraints, of different international policy options. Indeed, it would not be unreasonable to suggest that these four external actors have not acted more forcefully in the past because of a host of complex political factors - as opposed to simple inaction and indecision, as Ibrahim suggests.

Turning to his proposal concerning the ICC, Ibrahim rightly points out that Myanmar is not a signatory to the Rome Statute and as such, a self-referral to the ICC would not be possible in this instance. Nevertheless, Ibrahim is of the view that the ICC should, in fact, commence its own investigation into the Rohingyas. This, too, remains a vague suggestion. As international lawyers will point out, prosecutions before the ICC require the identification of perpetrators and as such, it is unclear who Ibrahim sees as the potential perpetrators that could be brought to account-key members of the ruling military regime, Buddhist extremist monks who are members of the 969 Movement, or a combination of both? Moreover, it remains unclear from Ibrahim's suggestion how the ICC itself can be cajoled into focusing its gaze on Myanmar and the Rohingyas. In particular, who has the power, influence and means to persuade the ICC to investigate the question of the Rohingyas?

Despite these questions, Ibrahim's book forces us to contend with a pressing issue of international concern. In doing so, it places the situation faced by the Rohingyas under a glaring spotlight, thereby urging us to appreciate and understand it as a political problem, which although intrinsically connected to Myanmar's history and ongoing political developments, that merits greater attention in its own right. On balance, therefore, this is an instructive book-not only for scholars and students with different disciplinary interests but also, for all of us who believes that the question of preventing and punishing genocide amounts to a shared, international responsibility. 